\title{
Homo amicus - biće sreće, radosti i blaženstva
}

Maja Herman Duvel*

maja.herman3@gmail.com

https://orcid.org/0000-0001-9017-8985 https://doi.org/10.31192/np.19.1.3

UDK: $27-423.7$

177.67

17.023 .34

Pregledni članak / Review

Primljeno: 24. srpnja 2020.

Prihvaćeno: 29. listopada 2020.

Čovjek je tražitelj sreće zato što je osoba. Stoga pitanje o ljudskoj sreći uključuje moralni život, ali ga i nadilazi. Svrha moralnoga života je ono dobro zahvaljujući kojemu ljudsko djelovanje $i$ sam čovjek postaju dobri. Takvo dobro su kreposti, no čovjek ih zbog svoje krhkosti i nemoći teško stječe. Zato je istinsko prijateljstvo privilegirano mjesto i pomoć za rast u kreposti $i$ životnoj radosti. Prijateljstvo ujedno može biti poticajno okružje za naporan rad traženja istine i za misleno motrenje Boga, koje čovjeka čini blaženim. No usprkos svojoj vrijednosti, ljudsko prijateljstvo i filozofska mudrost ostaju ograničeni. Čovjek vlastitim naporima ne može dokraja ispuniti svoju žudnju za ljubavlju, istinom i savršenstvom. Zato kršćanska teologija dopunjava filozofiju koncepcijom prijateljstva s Bogom. Po tom prijateljstvu ostvaruje se savršeno ozbiljenje ljudske osobe $i$ jedinstvo subjektivnosti $i$ objektivnosti, imanencije $i$ transcendencije, primanja $i$ davanja, koje je započelo ljudskim prijateljstvom.

Ključne riječi: blaženstvo, Bog, osoba, prijateljstvo, radost, sreća.

\section{Uvod}

Povijest filozofije bilježi dvije koncepcije međuljudskih odnosa. Prvu je Thomas Hobbes izrekao Plautovim stihom homo homini lupus est. U današnjoj situaciji pandemije bolesti COVID-19 takav stav animoziteta i straha je u nekom smislu postao društveno ozračje. No povijest filozofije nudi i drugu koncepciju, koja je prožeta etičkim, političkim i metafizičkim naukom Platona, Aristotela, Augustina, Boetija i Tome Akvinskoga te suvremenih autora, poput Bubera,

\footnotetext{
* Maja Herman Duvel, mag. phil., Sveučilište u Zagrebu, Fakultet hrvatskih studija, Borongajska cesta 83d, HR-10000 Zagreb.
} 
Philippea, Rouvilloisa, koji pak zastupaju da je čovjek po naravi prijatelj, homo amicus.

Srž potonjeg shvaćanja tvori tvrdnja da ljudi po naravi teže za srećom. Pritom tu težnju mogu pokušati ispuniti zadovoljenjem vlastitih potreba, prohtjeva i želja koji omogućuju izravno iskustvo užitka i zadovoljstva. No čovjek se u svom traženju sreće može okrenuti i k duhovnim zbiljnostima kao što su to druga osoba i Bog. Čovjek prijatelj na taj način svoju naravnu težnju za srećom - shvaćenu u najuobičajnijem, svakodnevnom značenju kao osjećaj zadovoljstva ili užitka - preobražava u doživljaj radosti, tj. u životni dobrobitak ili određeno samoozbiljenje, a zahvaljujući prijateljstvu s Bogom, on može postati i dionikom božanske radosti, tj. njegova blaženstva.

\section{Put usmjerenja k osobi u traženju sreće}

Sreća je jednostavna stvarnost, no teško ju je objasniti. Neka nam u analizi sreće posluži nekoliko pitanja: Koji su izvori sreće? Što je sreća? Tko traži sreću? Zašto tražimo sreću?

Odgovarajući na prvo od četiri navedena pitanja Platon u dijalogu Gozba veliča moć prijateljske ljubavi kao ljudske i božanske zbilje kojom se ostvaruje savršeno jedinstvo života između ljudi s jedne, te između ljudi i bogova s druge strane. Prijateljstvo je božanski oblik življenja zahvaljujući kojemu se možemo uzdići do motrenja lijepoga u sebi te je ono stoga izvor svakoga blaženstva. ${ }^{1}$

Aristotel u spisu Nikomahova etika navodi različita mišljenja o tome što je sreća ili blaženstvo. Tako najprimitivniji drže da je ono u posjedovanju dobara koja zadovoljavaju ljudske požude i osjetila, poput užitka ili bogatstva. Drugi pak smatraju da je u časti ili krepostima koje omogućuju politički i moralni život, a treći blaženstvo nalaze u motrenju koje uzdiže i usavršava ljudski um. ${ }^{2}$ Aristotel argumentira da je blaženstvo »nekakva djelatnost duše u skladu s krepošću. $\aleph^{3}$ Budući da je misaono motrenje najuzvišenije i najbožanskije djelovanje, najblaženiji je onaj život koji je u skladu s umnom kreposti mudrosti. Tomu blaženstvu je pridruženo i drugotno blaženstvo, koje je u skladu s moralnim krepostima. ${ }^{4}$ U VIII. i IX. knjizi spomenutoga djela, Aristotel ističe važnost prijateljstva, jer bez njega ne bismo mogli biti istinski i ustrajno kreposni ili dobri. Prijateljstvo je, znači, moralna krepost, ali je ujedno i nešto više jer sadržava kreposti. ${ }^{5}$ Prijateljstvo se živi u uzajamnoj dobrohotnosti koja kazuje da

${ }^{1}$ Usp. PlATON, Simpozij ili O ljubavi 188 d, 211 a-b, Eros i filia. Simpozij ili O ljubavi. Lisis ili O prijateljstvu, prev. Zdeslav Dukat, Zagreb, Demetra, 1996, 64-65, 126-129.

2 Usp. ARISTOTEL, Nikomahova etika I 4-5, 1095 b 14-1096 a 10, prev. Tomislav Ladan, Zagreb, Globus, 1988, 4-5.

${ }^{3}$ Isto, I 9, 1099 b 26, 15.

${ }^{4}$ Usp. isto, X 8, 1178 a 8, 232.

${ }^{5}$ Usp. isto, VIII 1, 1155 a 1, 165. 
prijatelji žele dobro jedan drugome poradi njih samih. ${ }^{6}$ Time Aristotel naučava da je čovjeku za blažen život potrebna pomoć - kako pojedinaca, tako i države.

Augustin je u djelu Ispovijesti opisao svoj životni put traženja sreće u veoma različitim dobrima, od onih osjetilnih, preko poslovnih, društvenih i intelektualnih, pa sve do otkrića najvišeg i osobnog dobra u Bogu. ${ }^{7}$ Pritom je spoznao da savršenu sreću nije moguće postići u ovom životu jer on nije vječan. ${ }^{8}$ Ona je moguća tek nakon smrti i uskrsnuća, i to isključivo nezasluženom božanskom milošću, a ne ljudskim djelovanjem. ${ }^{9}$ Bog je Bog ljubavi i njegov poziv da mu čovjek odgovori ljubavlju jest najuzvišeniji put prema krajnjoj sreći ${ }^{10}$

Boetije u III. knjizi djela Utjeha filozofije donosi nekoliko definicija sreće, od kojih najpoznatija kaže da je »istinska sreća savršeno stanje koje se postiže sjedinjenjem svih dobara «. ${ }^{11}$ Ljudi nastoje doći do toga najvišega dobra na različite načine: stjecanjem bogatstva, časti, moći, slave i užitka. Boetije iznosi zahtjeve koje najviše dobro treba ispuniti, zahtijevajući - kao što smo vidjeli da je potrebna cjelokupnost svih dobara te time ujedno izriče da taj kriterij ne ispunjava nijedno partikularno dobro, kao ni sva uzeta zajedno. Dokazujući postojanje najvišega dobra argumentira poistovjećivanjem najvišega dobra i Boga.

Toma Akvinski u djelu Suma teologije ističe da je svako promišljeno ljudsko djelovanje motivirano urođenom težnjom za srećom. Sve što čovjek želi, za tim teži misleći da se tu nalazi sreća ili da to pomaže na putu do postizanja sreće. Sreća je postizanje konačne svrhe, a to je Bog prema kojemu je čovjek usmjeren. Savršena sreća je $\mathrm{u}$ »savršenoj spoznaji Boga «. ${ }^{12}$ Na sličan se način u Komentaru na Matejevo evanđelje Akvinac osvrće na četiri različita mišljenja o tome da je sreća u obilju vremenitih dobara, življenju prema svojoj volji, vrlinama aktivnoga života ili vrlinama kontemplativnoga života. Smatra da prva dva mišljenja nisu točna jer je Isus bio siromašan i siromašne je proglasio blaženima, baš kao i milosrdne, krotke, ožalošćene te gladne i žedne pravednosti. Oni koji moralnošću nastoje postići sreću su, prema Tomi, manje u zabludi, s time da su moralne vrline put prema blaženstvu, a ne sâmo blaženstvo. Posljednje mišljenje Toma smatra najtočnijim, te mu nadodaje da se motrenje Boga ne odnosi na ovaj život, već na razdoblje nakon smrti (in patria). Sva ta mišljenja

\footnotetext{
${ }_{6}^{6}$ Usp. isto, VIII 1-3, 1155 b 16-1156 b 24, 167-170.

7 Usp. Aurelije AUGUSTIN, Ispovijesti, X, 27, 38, prev. Stjepan Hosu, Kršćanska sadašnjost, Zagreb, 1973, 230-231.

${ }^{8}$ Usp. Aurelije AUGUSTIN, O državi Božjoj (De civitate Dei) 19, 4, prev. Tomislav Ladan, Zagreb, Kršćanska sadašnjost, 1995, sv. III, 23-31.

9 Usp. Augustin, O državi Božjoj (De civitate Dei) 14, 1; sv. II, 231.

${ }^{10}$ Usp. Mathijs LAMBERIGTS, Augustine on Predestination. Some Questiones Disputatae Revisted, u: Augustiniana, 54 (2004) 279-305, 305.

${ }^{11}$ BOETIJE, Utjeha filosofije, III 2, Podgorica, Oktoih, 1999, 114.

${ }^{12}$ Usp. Toma AKVINSKI, Summa theologiae, I, q 1, a 4, Izabrano djelo, prir. Anto Gavrić, Zagreb, Nakladni zavod Globus, 2005, 277.
} 
nadilazi nagrada koju Gospodin obećava i prema kojoj vodi one koji primaju njegov nauk, a ta nagrada je sâmo blaženstvo. ${ }^{13}$

Srednjovjekovni arapski autori, kod kojih se uočava snažan Aristotelov utjecaj, također povezuju traženje sreće i Boga. Kreposti su prema njima sposobne preobraziti ljudsku narav tako da ljudska duša postiže svoj vrhunac u istinskoj sreći, ispunjenju i zamahu koje je u izravnom viđenju nestvorene Zbilje. ${ }^{14}$

Iznijet ćemo i dva primjera koja nam govore o današnjem shvaćanju sreće. Ujedinjeni narodi svake godine objavljuju Izvješće o sreći u svijetu..$^{15}$ Zemlje pritom rangiraju prema šest ključnih varijabli koje se smatraju temeljnima za ljudski dobrobitak: bruto domaći proizvod po stanovniku, društvena podrška, očekivani životni vijek u zdravlju, sloboda u donošenju životnih odluka, velikodušnost (davanje u humanitarne svrhe) i percepcija korupcije. Pritom se nastoje promotriti i objektivni učinci sreće i subjektivni dojmovi. Spomenimo još studiju Sveučilišta Harvard o razvoju odraslih, koja je provođena na nekoliko stotina ljudi tijekom 79 godina koji su redovito davali detaljna izvješća o svom zdravlju, odnosima, uspjesima i prošlosti. ${ }^{16}$ Studija je pokazala da ispitanici istinsku sreću i zadovoljstvo nisu našli u novcu i u slavi, već je ključ za sretan i ispunjen život bio u zdravim međuljudskim odnosima.

Analiziravši problem izvora sreće, osvrnut ćemo se na pitanje što je sreća, što se to događa kada iskusimo sreću. Slijedeći Rouvilloisovu misao zamjećujemo da sreća nije nekakvo stanje jer svaki način postojanja uključuje trajnost, dok je sreća samo povremena. ${ }^{17}$ Sreća nije strast, iako ima sličnu dinamiku. Nije ni puki užitak ili zadovoljstvo koje možemo postići nekim sredstvima i metodama tako da sredstva možemo posjedovati, a metode naučiti. Ona prolazi kroz naš život a da je ne možemo zaustaviti, zaposjesti ili proizvoditi. Sreća nije ni krepost niti plod kreposti, jer možemo prakticirati razboritost, pravednost, hrabrost i ostale kreposti i pritom ne ćutiti sreću. Ona nije učinak nekog svjesnog čina, kao ni vlastitost dobra jer dobro možemo činiti i da nismo sretni. Sreća se razlikuje i od smijeha i humora koji ostaju imaginarni i djelomice apstraktni. Ona uključuje i iznenađenje pa se tako obradujemo kada doživimo nešto neočekivano, kao kad nam se netko nenadano osmjehne, no pritom nije

\footnotetext{
${ }^{13}$ Usp. Toma AKVINSKI, Super Evangelium S. Matthaei lectura, cap. 5 I. 2, http://www.corpusthomisticum.org/cma0500.html (15.07.2020).

${ }^{14}$ Usp. Anto GAVRIĆ, Poimanje sreće u arapskih filozofa, u: Mijo NIKIĆ, Kata LAMEŠIĆ (ur.), Religije i sreća, Zagreb, FTI DI, 2014, 57-78.

${ }^{15}$ Usp. World Happiness Report (2019); https://worldhappiness.report/ed/2019/ (15.07.2020).

${ }^{16}$ Usp. Robert WALDINGER, What makes a good life? Lessons from the longest study on happiness, (05.2015); https://www.ted.com/talks/robert_waldinger_what_makes_a_good_life_lessons_from_the_longest_study_on_happiness?language=en (15.07.2020).

${ }^{17}$ Usp. Samuel ROUVILLOIS, La joie, (04.01.2017); http://www.conferencedesamarie.com/telecharger-historique/ (15.07.2020). Samuel Rouvillois (1961-), francuski filozof i teolog, autor nekoliko djela, zauzet u promicanju poslovne etike u poslovnom svijetu te $u$ dijalogu između Crkve i svijeta kulture.
} 
puka igra slučaja ili sretnih okolnosti, jer mi i svojim činima utječemo na svoju sreću. ${ }^{18}$

Iz rečenoga je vidljivo da čovjek može doživjeti samo trenutke sreće. Mi sreću ne možemo zaposjesti ili trajno u njoj boraviti. Zašto je to tako? Rouvillois objašnjava da je razlog tomu radikalna ljudska nedovršenost. Čovjek je biće podložno i sklono promjenama, biće u trajnom postajanju i razvoju. Zato za nas sreća može biti samo časovita. Autor na koncu primjećuje da u trenucima sreće kao da dodirujemo puninu, kao da kroz naš život prođe punina. Sreća nas $\mathrm{u}$ trenutku naprosto ispuni.

Iskustvo punine otvara nam treće pitanje: Tko to traži sreću? Osjećaj sreće je zajednički i ljudima i životinjama, no samo čovjek kao slobodno razumsko biće može donositi bolje ili lošije odluke u odabiru onoga što je za njega dobro. Zato je čovjek tražitelj sreće - upravo zato što je osoba. Da bismo objasnili što je to ljudska osoba, oslonit ćemo se na misao M.-D. Philippea ${ }^{19}$ koji na osobu gleda kao na »kako« (comment) ljudskog bića, kao na način postojanja. Ljudska osoba je »kompleksna individuirana supstancija, sastavljena od duhovne duše i organskoga tijela.$^{20}$ Čovjek je na taj način autonoman i jedinstven individuum koji posjeduje brojne kvalitete i odnose s materijalnim svijetom, živim bićima i ljudima. Kao osobu ga ne određuje samo takva njegova struktura, već i ono što ga privlači tako da ga kao realno dobro koje ga nadilazi može usavršiti, finalizirati. $^{21}$

Koje je to dobro koje ljudsku osobu može učiniti sretnom? Čovjek nije sretan naprosto samo zato što postoji, samo zato što živi. Njegova sreća nije ni u njemu samome jer je ograničeno biće koje »traži dobro koje ga budi, čini da raste, koje mu omogućava da se razvije u onome svome najboljem i najdubljem, tj. onome najljudskijem «. ${ }^{22}$ Čovjek može učiti, rasti, razvijati se u susretu sa

${ }^{18}$ Usp. Ivan ŠESTAK, Toma Akvinski o sreći i blaženstvu, Zagreb, FTI DI, 2018, 43.

${ }^{19}$ Marie-Dominique Philippe (1912-2006), francuski filozof i teolog, pripadnik struje aristotelizma i tomizma, autor više od 35 knjiga iz područja metafizike, etike, filozofije rada, mistične teologije dr.

${ }^{20}$ Marie-Dominique PHILIPPE, Lettre à un ami. Itinéraire philosophique, Pariz, Editions Universitaires, 1990, 128. Philippe se tu vidljivo oslanja na Boetijevu definiciju osobe kao naturae rationalis individua substantia (BOETHIUS, De Persona Christi et duabus naturis, Patrologiae cursus completus, accurante J. P. MIGNE, Series Latina, t. 64. Parisiis, 1891, 1343), ali ukazuje na onu bitnu razliku između pojmova osobe i ljudske osobe: na ljudsku kompleksnost u supstancijalnom jedinstvu, na sastavljenost od duše i tijela. Duša je počelo i uzrok života organskoga tijela kao njegova forma i ono što ga animira. Ona je počelo različitih stupnjeva života: vegetativnog, osjetilnog i duhovnog. Duhovni život je najimanentniji jer uključuje aktivnosti uma i volje. Tijelo pak nije nešto sekundarno, akcident, već je supstancijalna uvjetovanost osobe (Philippe, Lettre... 68; Marie-Dominique PHILIPPE, Retour à la source, sv. I, Pour une philosophie sapientiale, Pariz, Fayard, 2005, 423).

${ }^{21}$ Misao se oslanja na Aristotelov iskaz da je »dobro ono čemu svi teže« (Aristotel, Nikomaho$v a . . .$, I 1, 1094 a 4, 1). Vlastiti učinak dobra je da privlači, da pobuđuje ljubav. Ako je to dobro duhovno, ono pobuđuje duhovnu, voljnu ljubav koja uključuje neko znanje (usp. Philippe, $R e-$ tour..., 190).

${ }^{22}$ Isto, 129. 
svim bićima, ali njegova voljna, duhovna ljubav budi se u susretu s duhovnim, osobnim dobrom. I ako mu ta druga osoba uzvrati ljubavlju, tada njihova ljubav, zahvaljujući toj uzajamnosti, postaje još dublja. Zato Philippe može zaključiti da je za razumijevanje čovjeka ključno shvatiti da je »ljudska osoba finalizirana samo kada voli drugu ljudsku osobu koju je u uzajamnoj ljubavi izabrala za svoga prijatelja«. ${ }^{23}$

Na koncu se možemo pitati i zašto tražimo sreću. Tražimo li je kao svoj finalitet, svoju svrhu? To bi značilo da svoju svrhu smještamo u nešto prolazno te tako ne bismo nikada nužno dosegli željeni stupanj sreće. Povrh toga, svoj finalitet bismo smještali i u nešto nama imanentno, što bi se također pokazalo kao jalovo nastojanje budući da kao ograničena i nesavršena bića nemamo i ne možemo imati puninu svoga bitka u sebi.

$\mathrm{Na}$ temelju odgovora na sva četiri pitanja možemo zaključiti da nas naša naravna težnja za srećom usmjerava ne samo k onome nama imanentnom $u$ dobru, nego i k nekom drugom dobru koje nas, zato što je drugo, nadilazi odnosno transcendira. Taj spoj subjektivnog i objektivnog aspekta u traženju sreće tvori svu kompleksnost ljudskog djelovanja. Na najeminentniji način ga živimo u odnosu uzajamne ljubavi kojeg nazivamo prijateljstvom. Sreća tada prestaje biti nekakav objekt kojeg tražimo i prerasta u plod uzajamne ljubavi dvaju prijatelja. Taj plod nazivamo radošću.

\section{Prijateljstvo kao izvor najveće ljudske radosti}

Prijateljstvo je vrsta duhovne ljubavi koja ima svoj razvojni proces i svoje ključne etape. Ono se začinje iskustvom žudnje koje je vrsta duhovnog pokreta, elana ili dinamizma koji nas usmjerava $\mathrm{k}$ dobru i potiče nas na djelovanje. Pri tom okretu prema željenomu dobru mi činom ljubavi izlazimo iz sebe. ${ }^{24}$ To usmjerenje k drugoj osobi u prvom se redu odnosi na njezine osjetilne kvalitete koje u nama pobuđuju tjelesno i vremenski ograničenu osjetilnu i strasnu ljubav koja ostaje individualna, egocentrična. No žudnja nas postupno usmjerava i k onomu što u nama budi duhovnu ljubav, k dobru koje može postati vlastito ljudsko dobro. Tako se, ponad prisutnosti i afektivnosti, u našoj volji kao sposobnosti da volimo duhovnom ljubavlju, budi istinska duhovna ljubav. Ona se »odnosi na osobu i svoj pun razvoj doseže u prijateljskoj ljubavi«. ${ }^{25}$ Duhovno dobro je osobno, a osoba uključuje tijelo, osjetilnost, afektivnost, maštu, duh. Mi svoga prijatelja volimo u svemu što on jest i sa svime što mi jesmo. ${ }^{26}$ Martin

\footnotetext{
${ }^{23}$ Isto.

${ }^{24}$ Usp. isto, 183.

${ }^{25}$ Isto, 184.

${ }^{26}$ Usp. Marie-Dominique PHILIPPE, Les Trois Sagesses, Pariz, Fayard, Aletheia, 1997, 104-105; Philippe, Retour..., 346.
} 
Buber bi rekao da »ljubav nije slijepa, tj. ona vidi cijelo biće« ${ }^{27}$ Tako nam žudnja koja pobuđuje našu duhovnu ljubav omogućava da rastemo, da se razvijamo. Rast ljudske osobe je na tom području najvidljiviji jer ljubav nema mjere. Ona je izvor daljnje ljubavi i potiče nas da idemo još dalje, da uvijek sve više volimo. Kada bi ljubav prestala rasti i produbljivati se, jednostavno bi prestala biti ono što ona jest. ${ }^{28}$ Nakon buđenja želje da pobliže upoznamo neku osobu slijedi prelazak na djela jer ako se ljubav ne bi odvažila krenuti u osvajanje, ostala bi na razini imaginarne afektivnosti. Tu se možemo susresti s brojnim poteškoćama, osobito ako je u pitanju duboka, životna nakana čije je ozbiljenje važno za naš ljudski razvoj. Zato često tražimo savjet od onih koji su na tom području iskusniji od nas. ${ }^{29}$

Privlačnost i unutarnji stav ljubavi prerastaju u prijateljstvo u trenutku kada nam osoba koju volimo odgovori ljubavlju. Ključan je moment u tom prijelazu uzajamni prijateljski odabir, kada se prijatelja odabire radi njega samoga, zbog onoga što on jest, u činu koji je istodobno i pasivan i aktivan. ${ }^{30}$ I u toj svijesti prijateljskog odnosa uzajamna ljubav doseže nov i jedinstven intenzitet i karakter. Možemo reći da prijateljskim odabirom čovjek stječe novi identitet: on postaje prijatelj, homo amicus.

Rekli smo da je, da bismo se mogli susresti s drugom osobom koja nas privlači, potrebno da iziđemo iz sebe, da se nadiđemo i darujemo u ljubavi. To znači da je duhovna ljubav ekstatična, s time da »ekstaza « ${ }^{31}$ uključuje ne samo izlaženje i nadilaženje, već i prihvaćanje onoga koga volimo. Na taj način nam uzvraćena ljubav ili uzajamni dar ljubavi omogućuje pounutrašnjenje i rast $u$ sposobnosti da volimo, ${ }^{32}$ omogućuje nam da otkrijemo i postanemo ono što mi istinski jesmo jer »ljudska osoba može biti savršeno ono što ona jest jedino kad nadilazi sebe ${ }^{33}$

Prijatelj je, dakle, naše osobno dobro i mi smo njegovo osobno dobro. On je onaj koji svojom ljubavlju u nama budi ljubav, koji nas usavršava, čini da rastemo i otkrijemo tko smo mi ustvari, koja je naša svrha. Prijatelja volimo i radi svoga dobra i radi njega samoga, i to dvoje je povezano. Ono ja jesam i ovo jest, koje mnogi filozofski sustavi odvajaju, ovdje se na osobit način sjedinjuju. Prijateljstvo, prema tome, označava dva tipa iskustva: unutarnje i vanjsko. Ljubav donosi unutarnje iskustvo: iskustvo naše ljubavi prema prijatelju i iskustvo spoznaje zahvaljujući kojoj smo odabrali svoga prijatelja i pomoću koje gradimo

\footnotetext{
${ }^{27}$ Martin BUBER, Ja i ti, Beograd, Vuk Karadžić, 1977, 38.

${ }^{28}$ Usp. Philippe, Retour..., 181.

${ }^{29}$ Usp. isto, 187.

${ }^{30}$ Usp. Buber, Ja i ti..., 34.

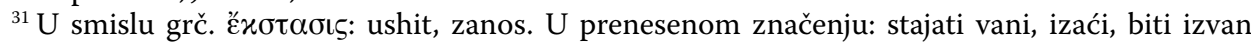

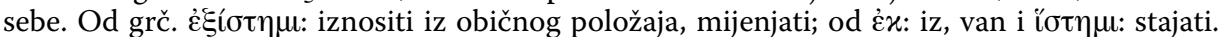

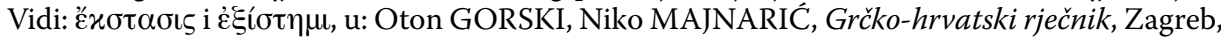
Školska knjiga, 2005, 126 i 142.

${ }^{32}$ Usp. Philippe, Lettre..., 37.

${ }^{33}$ Philippe, Retour..., 399.
} 
istinsko prijateljstvo. Što se tiče vanjskog iskustva, ono se odnosi na konkretan, tjelesni doticaj između prijatelja. Bez njega bi prijateljstvo lako izgubilo na svojoj snazi i palo u drugi plan. Zato nam je potrebna prisutnost i blizina našega prijatelja koja nam omogućuje da na temelju iskustva znamo da nas prijatelj voli. ${ }^{34}$ Stoga možemo s Aristotelom reći da se prijateljski odnos temelji na zajedništvu te da prijatelji provode vrijeme zajedno, baveći se onim što vole i ostvarujući neko zajedničko djelo. ${ }^{35}$

Na koji način se oslikavaju ljubav prema sebi i ljubav prema prijatelju? Philippe napominje da su te dvije ljubavi bitno različite, ali i povezane. ${ }^{36}$ Prijatelja volimo poradi njega samoga, kao osobu, takva kakav on jest, a ne poradi samih sebe, zato što on nas voli. To znači da nas prijateljska ljubav u svom realizmu izbavlja od intencionalnosti i omogućuje da dosegnemo drugoga u njegovoj drugosti i drugačijosti, kao onoga koji postoji izvan nas. No budući da prijateljstvo istodobno zahtijeva uzajamnost, prijatelj postaje i naše osobno dobro koje u nama pobuđuje ljubav i razvija osobnu dobrotu.

To rekavši možemo se zapitati kako to da neka osoba može biti istinsko dobro za neku drugu osobu, a ne može biti svoje vlastito dobro. Philippe u svom odgovoru ukazuje na razliku između determiniranja i finaliziranja. Ljubav prema sebi kazuje da smo mi sami sebi svoje vlastito dobro i ta je ljubav nužan preduvjet za prijateljsku ljubav te je determinira. Ali u ljubavi prema samima sebi naša dobrota i ljubav ostaju ograničene i imanentne jer mi nismo savršena bića koja su beskrajna u dobroti i ljubavi. Zato ne možemo sami sebe usavršiti, ne možemo samima sebi biti svrhom. No budući da je naša duhovna želja da volimo u nekom smislu neograničena, naša volja i um su otvoreni prema cjelokupnoj zbilji, otvoreni su za ono beskrajno. Zato nas druga osoba može dijelom ozbiljiti jer ona je u svojoj dobroti netko drugi. Isto tako, mi možemo dijelom usavršiti neku drugu ljudsku osobu. Razlog tomu je taj da

»dobro ima istinsku moć privlačnosti. Egzistencijalni alteritet je uvjet za takvu privlačnost. Egzistencijalni alteritet nije ono što privlači, već on omogućuje da ograničeno dobro privuče jednu drugu, također ograničenu osobu. Zahvaljujući tom alteritetu, ljudska osoba može biti za drugu ljudsku osobu izvor istinskoga ostvarenja, usavršavanja, istinska svrha. « ${ }^{37}$

Na sličan način Philippe objašnjava zašto naša svrha ne može biti duhovna ljubav koju gajimo prema svome prijatelju, već naš prijatelj osobno. ${ }^{38}$ Ljubav kojom volimo svoga prijatelja ostaje ono što mi živimo u sebi. Prijatelj je, naprotiv, realno dobro, realno biće koje postoji. On nas kao drugi uvijek nadilazi i komplementaran nam je. Kada otkrijemo da je on drugi, to znači da smo otkrili

\footnotetext{
${ }^{34}$ Usp. Philippe, Lettre..., 35; Philippe, Retour..., 346.

${ }^{35}$ Usp. Aristotel, Nikomahova..., VIII 9, IX 12, 1159 b 25 - 1160 a 30, 1172 a 1-6, 178-179, 213.

${ }^{36}$ Usp. Philippe, Retour..., 189.

${ }^{37}$ Isto, 190.

${ }^{38}$ Usp. isto, 234, 396.
} 
da nas nadilazi, da ima nešto što mi nemamo, da je vrijedan našega divljenja. Zato se u prijateljskoj ljubavi ne samo konaturaliziramo s osobom koju volimo, nego i unutar te konaturalnosti koja nas sjedinjuje nadilazimo sami sebe.

U svojoj analizi prijateljstva Philippe primjećuje da zahvaljujući prijateljskoj ljubavi možemo otkriti da je »ono što se najviše može voljeti u nekoj osobi njezina orijentacija prema njezinoj svrsi. I upravo to je dobrota neke osobe « ${ }^{39}$ Zato je za nas prijateljska ljubav apsolut, a istinsko prijateljstvo je vrhunac koji može usavršiti naš moralni život. Homo amicus je usmjeren na to da djeluje moralno, da stječe i razvija one habituse koje nazivamo krepostima, a koji mu omogućuju djelovati brže, lakše i plemenitije u ostvarenju svoje moralne nakane. Zato je prijateljstvo ujedno i iskustvo u kojemu se prvo budi smisao za odgovornost.

Prijateljstvo je izvor najsnažnijih trenutaka sreće. Oni nas mogu krijepiti i nositi u vremenu nesreće. No prijateljstvo ide i puno dalje jer duhovna radost, koju doživljavamo zahvaljujući svome prijatelju, može nadići trenutke krize, boli i tuge. Ona se, dapače, u tim trenucima može još i produbljivati rastom naše međusobne ljubavi i bliskosti.

Ta razlika između sreće i radosti postaje veoma vidljiva ako se poslužimo etimologijom drevnoga grčkog pojma $\varepsilon \dot{v} \delta \alpha \mu \mu$ oví $\alpha$, kao što to čini Peter Kreeft u svom predavanju o sreći. ${ }^{40}$ Prefiks $\varepsilon \dot{v}$ - (»dobro «) izriče potrebu da budemo moralno dobri da bismo bili sretni; korijen $\delta \alpha i ́ \mu \omega \nu$ (»duh«) kazuje da je sreća stvar ljudskoga duha te stoga uključuje ljudsku slobodu i odgovornost; sufiks

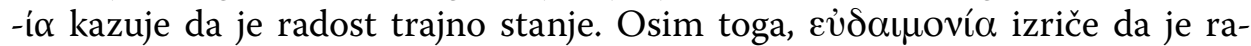
dost objektivno stanje, dok je sreća ili zadovoljstvo subjektivan doživljaj. Prava, istinska radost uključuje i zadovoljstvo, unutarnji mir i barem minimum bogatstva, ali se ne ograničuju na to. Istinsko prijateljstvo uključuje sve navedene odlike: moralnost, slobodu, odgovornost, trajnost, objektivnost. Možemo, dakle, reći da je prijateljstvo izvor ne samo najsnažnijih trenutaka sreće, već i istinske ljudske radosti.

No prijateljstvo istodobno zahtijeva visok stupanj osobne zrelosti i kreposnoga življenja. Da bi ono postalo našim istinskim ozbiljenjem, potrebno je da prijatelja želimo radi njega samoga, da ga poznajemo radi njega samoga, volimo radi njega samoga i po njemu samome. Upravo zbog te zahtjevnosti, istinska prijateljstva su veoma rijetka. Kada naš prijatelj prestane biti naše osobno dobro, prijateljstvo lako sklize u ono što nas ne može ozbiljiti, usavršiti, finalizirati. Prijateljstvo može izblijediti i propasti na razne načine, primjerice uspoređivanjem, rivalstvom, ljubomorom, koristoljubljem, egoizmom, izdajom.

Osim navedenih poteškoća, može se dogoditi i da jednostavno ne uspijemo susresti osobu kojoj bismo se mogli povjeriti tako da se izgradi odnos uzajamne ljubavi. Za čovjeka je to velik nedostatak jer svi mi čeznemo za prijateljem. Phi-

\footnotetext{
${ }^{39}$ Isto, 348.

${ }^{40}$ Usp. Peter KREEFT, Happiness, (2011) https://www.youtube.com/watch?v=fp0tIhW1YyY (15.07.2020).
} 
lippe međutim primjećuje da i žeđ za prijateljstvom, koja postoji u srcima svih ljudi, može biti dovoljna za rast u osobnoj dobroti. ${ }^{41}$ No ponad svega, čovjek se može zaputiti prema traženju Bića koje nas nadilazi jer je netko Drugi i s kojim može stupiti u odnos zato što je Osoba. Ako je takvo što moguće, pred čovjekom se otvara mogućnost apsolutne ljubavi i dara čiji plod neće biti samo povremena sreća, nego blaženstvo.

Prijateljska ljubav je izvor nevjerojatne životne snage i energije. No budući da je potpuno ovisna o dobru, o onome tko nam se daje, čini nas i ranjivijima, osjetljivima, izloženijima patnji. ${ }^{42}$ Kada volimo, gubimo svoju zaštićenost i sigurnost. Zato možemo reći da nas ljubav obogaćuje, ali i osiromašuje: kada joj se naime predamo, mi nekako gubimo svoju moć, ozbiljnost i autoritet. ${ }^{43} \mathrm{Zbog}$ različitosti među prijateljima i promjenjivih životnih okolnosti prijateljstvo poznaje i mnoge druge krhkosti. No svako prijateljstvo je obilježeno još jednom, i to nepremostivom krhkošću i limitom, time što su oba prijatelja ograničena u svome postojanju. Smrt prijatelja strašan je i neshvatljiv gubitak za ljudsku osobu. ${ }^{44}$ Pritom se bude nebrojena pitanja: Kako to da prijateljstvo, koje je za nas takav apsolut može biti tako ograničeno? Postoji li nekakav odnos koji bi bio jači od smrti? Zašto mi i dalje nastavljamo voljeti svoga prijatelja kada njega više nema?

\section{3. Življenje blaženstva u osobnom odnosu s Bogom}

Smrću našega prijatelja prestaje naše prijateljstvo, a time i izvor naše najveće sreće i radosti. Mi se nastavljamo prisjećati lijepih trenutaka provedenih s prijateljem, no oni u nama podjednako pobuđuju smješak i nostalgiju. Na taj način nas iskustvo ili mogućnost gubitka prijatelja dovodi do pitanja o postojanju Boga u kojemu jedinomu čovjek ne bi našao samo svoju krajnju sreću, radost i blaženstvo, nego bi i on sâm bio punina radosti, života, blaženstva.

I za Bubera i za Philippea Bog nije predmet dokazivanja. On je osoba koju možemo otkriti, susresti i o njoj svjedočiti. ${ }^{45}$ Ako je Bog bitak koji postoji sam po sebi ili sama zbiljnost bivstvovanja ${ }^{46}$ koju možemo dodirnuti po svakom po-

\footnotetext{
${ }^{41}$ Usp. Philippe, Les Trois..., 100.

${ }^{42}$ Usp. Samuel ROUVILLOIS, Le corps (07.11.2001), http://www.conferencedesamarie.com/telecharger-historique/ (15.07.2020).

${ }^{43}$ Usp. Rouvillois, La joie..., 2017.

${ }^{44}$ Tako Aurelije Augustin opisuje svoju duboku bol zbog gubitka prijatelja jer su bili »jedna duša u dva tijela " (usp. AUGUSTIN, Ispovijesti, IV, 4-6, Zagreb, Kršćanska sadašnjost, 2007, 58-61). Smrt dragog prijatelja učinila je to da je Augustin »sam sebi postao veliko pitanje«, jer, iako je pitao svoju dušu »zašto je žalosna i zašto me silno uzbuđuje«, nije nalazio odgovor (usp. isto, 59).

${ }^{45}$ Usp. Buber, Ja i ti... 139; Philippe, Retour... 349.

${ }^{46} » I$ Ipsum esse subsistens «, Toma AKVINSKI, De ente et essentia, cap. 4, Summa teol. I, q 4, a 2. Prijevod: T. AKVINSKI, Izabrano djelo, 2005, 139, 307.
} 
jedinom biću, onda je on i osoba prisutna u svakoj prijateljskoj ljubavi. Bog bi bio onaj koji »postoji prije nas i prije našega prijatelja, on bi bio jamstvo našega postojanja i onaj koji nas privlači $u$ traženju istine i u ljubavi ${ }^{47}{ }^{47}$ Koja je onda uloga prijateljske ljubavi u otkrivanju Boga? Zahvaljujući njoj otkrivamo da prijateljska ljubav, iako dolazi od nas, postoji na takav način da teži k onomu što je prvo. Prijatelj je ograničen na razini bitka jer nema u sebi svoju svrhu i puninu, već je upućen na svoga prijatelja. No s druge strane, uzajamna ljubav je zbiljska, ona zbiljski ujedinjuje i finalizira. Kako shvatiti da tu istodobno postoje veliko metafizičko ograničenje u postojanju i čin ljubavi koji se finalizira? U svjetlu principa finaliteta prema kome biće-u-zbilji prethodi biću-u-mogućnosti, ${ }^{48}$ tj. »budući da moj ljubljeni prijatelj koji me privlači ne može biti izvor moga bitka«, ta ljubav dodiruje i priziva Boga, Osobnu dobrotu u kojoj se biće i ljubav poistovjećuju. ${ }^{49}$

Ova nam promišljanja otkrivaju koliko je prijateljstvo važno za filozofiju, za traženje istine.$^{50}$ Aristotel proglašava da je Bogu najmiliji te stoga najblaženiji

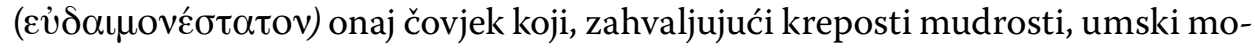
tri Boga.$^{51}$ Toma Akvinski potvrđuje da je mudrost najuzvišenija i najsavršenija krepost jer po mudrosti postajemo sličnima Bogu i sjedinjeni s njime. Krepost mudrosti je stoga najveći izvor blaženstva (beatitudinis). ${ }^{52}$

Riječ blaženstvo je u naš vokabular ušla kao prijevod grčkoga poetičnog pridjeva $\mu \alpha \dot{k} \alpha \rho$ i kasnijeg produženog oblika $\mu \alpha \kappa \alpha ́ p ı$. Kod Hezioda i Homera ta riječ označava božansku sreću koja nadilazi brige, muku i smrt, da bi u helenističkom razdoblju postala opći termin za sreću. ${ }^{53}$ Drugi izvor termina je Biblija. U Starom zavjetu susrećemo hebrejski izraz blago ili blaženstvo onih koji žive po Božju. Septuaginta ašre prevodi riječju

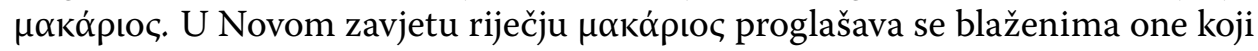
su u jedinstvu s Bogom jer žive i djeluju poput Krista. Razlog takvih proglasa je metafizički: Bog sâm je punina života i blaženstva, on osobno je radost ili blaženstvo. Tako apostol Pavao u 1 Tim 1,11 i 6,15 uz Božja imena navodi i to

\footnotetext{
${ }^{47}$ Philippe, Retour..., 349.

${ }^{48}$ Usp. ARISTOTEL, Metafizika, IX 6, 1048 a 32-33, prev. Tomislav Ladan, Zagreb, Globus - Sveučilišna naklada Liber, 1988, 224.

${ }^{49}$ Philippe, Lettre..., 124; usp. Philippe, Lettre..., 136; Philippe, Retour..., 349.

${ }^{50}$ Prijateljstvo se dugo držalo potrebnim okruženjem i ozračjem za filozofiranje i za naporno traženje istine. Papa Ivan Pavao II. ističe u enciklici Fides et ratio da su pravo prijateljstvo i pouzdani dijalog plodonosni za filozofska istraživanja (usp. Ivan Pavao II., Fides et ratio. Vjera i razum, Zagreb, Kršćanska sadašnjost, 1999, br. 33). Također usp. Charles MOREROD, Poziv katoličkog filozofa kao filozofa, u: Anto GAVRIĆ, Ivan ŠESTAK (ur.), Veritas vitae et doctrinae. U potrazi za istinom o čovjeku i Bogu. Zbornik u čast Hrvoja Lasića, OP., Zagreb, FTI DI, 2012, 21-39.

${ }^{51}$ Aristotel, Nikomahova..., X 8, 1179 a 22-32, 235.

${ }^{52}$ Usp. Toma AKVINSKI, Suma protiv pogana (Suma contra gentiles), I, kap. 2, sv. I, Zagreb, Kršćanska sadašnjost, 1993, 7.

${ }^{53}$ Usp. Marijan VUGDELIJA, Moralna dimenzija Isusovih blaženstava (Mt 5,1-12), Služba Božja, 52 (2012) 3-4, 285-340.
} 


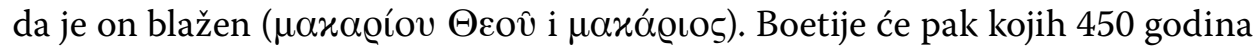
nakon Pavla napisati da je Bog kao vrhovno dobro ujedno i sâmo blaženstvo. ${ }^{54}$

Može li čovjek stupiti u odnos prijateljstva s Bogom? Mogu li Bog i čovjek postati prijatelji? Religiozni čovjek teži da kao stvorenje stupi u odnos sa svojim Stvoriteljem. Formalan čin koji mu na najizvrsniji način omogućuje da stupi u odnos sa svojim izvorom i iskaže svoju potpunu ovisnost o Stvoritelju naziva se poklonstvo. No zar poklonstvom čovjek ne postaje potčinjeno biće, sluga, rob, a ne prijatelj Božji? Misao o prijateljstvu Boga i čovjeka razvija se stoga u kršćanstvu s naukom da je Bog utjelovljenjem Sina Božjega načinio most između božanske i ljudske naravi, izrekavši to riječima: »Više vas ne zovem slugama jer sluga ne zna što radi njegov gospodar; vas sam nazvao prijateljima jer vam priopćih sve što sam čuo od Oca svoga« (Iv 15,15). To zajedništvo ili dioništvo u božanskoj naravi (2 Pt 1,4) znači i da čovjek počinje djelovati na božanski način. ${ }^{55}$

Rekli smo da se filozofski može zaključiti da je Bog kao vrhovno dobro ujedno i sâmo blaženstvo. S time se podudaraju Kristove riječi da u njemu trajno prebiva radost $\mathrm{i}$ da je razlog njegove radosti njegov odnos s Ocem. ${ }^{56}$ Budući da je, prema Tomi Akvinskomu, Kristov odnos s Ocem njegovo vlastito biće, ${ }^{57}$ Rouvillois zaključuje da je on ujedno Božja radost i da se ta radost daruje, priopćuje ljudima. ${ }^{58}$ Dijeljenjem te radosti koja je Bog sâm, čovjek dijeli i Božji život te se može nazvati Božjim prijateljem.

Božanska radost je, dakle, blaženstvo. To je punina koja je sam Bog. Takvu radost čovjek za života nikada ne može posjedovati. I kao što Buber primjećuje da je odnos između čovjeka i Boga potpun odnos u kojemu su trajno uključeni svi naši ostali odnosi, ${ }^{59}$ tako možemo i za blaženstvo reći da je ono punina koja sadrži i svu našu sreću i našu radost. Augustin je tu konačnu ljudsku svrhu koja jest čovjekovo blaženstvo nazvao gledanjem Boga, ${ }^{60}$ a Toma blaženim gledanjem, ${ }^{61}$ a ono je rezervirano za razdoblje nakon naše smrti, tj. in patria.

\footnotetext{
${ }^{54}$ Usp. Boetije, Utjeha..., 141. "Deum esse ipsam beatitudinem necesse est confiteri« (Anicii Manlii Severini BOETHII, Consolatio philosophiae, III, caput 10, 17, ed. S. J. Tester, H. F. Stewart and E. K. Rand, London, 1973, 271).

${ }^{55}$ Usp. THOMAE DE AQUINO, Scriptum super Sententiis, III, dist. 34, q 1, a 1, co., http://www. corpusthomisticum.org/snp3034.html (15.07.2020).

${ }^{56}$ Usp. Iv 15,9-11.

${ }^{57}$ Usp. Toma Akvinski, Summa theol. I, q 28, a 1 (ed. Leon., sv. IV, 318-319).

${ }^{58}$ Usp. Rouvillois, La joie, 2017.

${ }^{59}$ Usp. Buber, Ja i ti..., 116.

${ }^{60}$ Usp. AURELIJE AUGUSTIN, Opera omnia - editio latina, Patrologiae latinae elenchus, PL 34, De sermone Domini in monte, I, 4,12, https://www.augustinus.it/latino/montagna/index2.htm (15.07.2020).

${ }^{61}$ Usp. Toma Akvinski, Summae theol. I-II, q 1-5 (ed. Leon., sv. VI, 5-54).
} 


\section{Zaključak}

Čovjek je osobno biće obdareno razumom i slobodnom voljom i zato je sposoban uvidjeti da istinsku sreću ne može naći u materijalnim dobrima i u časti, te da sreća više ovisi o ljudskom djelovanju, nego o slučajnosti. Kada se u svom traženju sreće usmjeri k duhovnim, tj. osobnim zbiljnostima, može otkriti da je svrha moralnoga života kreposno djelovanje zahvaljujući kojemu ljudsko djelovanje i sam čovjek kao takav postaju dobri.

No moralni život je poradi ljudske krhkosti i nemoći toliko težak i mučan da čovjek sam po sebi jedva uspijeva težiti za krepošću. Potrebna mu je motivacija koja bi mu istodobno dolazila izvana i iznutra. Zato je prijateljstvo privilegirano mjesto nadilaženja samih sebe. Prijateljstvo omogućava da prijatelji, kroz uzajamnu duhovnu ljubav u kojoj se prijatelja voli i radi svoga dobra i radi njega samoga, tako da je to dvoje povezano, jedan u drugome prepoznaju svoje dobro koje ih dijelom ozbiljuje, usavršava i čini radosnima.

Usprkos svojoj vrijednosti, prijateljstvo ostaje ograničeno jer čovjek ne može sam po sebi niti zahvaljujući prijateljskom odnosu s drugim ljudima postići djelovanje i savršenstvo koji bi ga doveli do punine njegova ozbiljenja. Stanje krhkosti ga na taj način upućuje na postojanje krajnje dobrog i svemogućeg bitka, tj. Boga. U umnoj spoznaji i motrenju Boga čovjek djeluje prema najuzvišenijoj kreposti, mudrosti, i to djelovanje ga čini blaženim. Misaono motrenje čini krajnju točku filozofskog promišljanja o sreći i blaženstvu, ali ne i ljudske žudnje za ljubavlju, istinom i savršenstvom. Ispunjenje te žudnje je ostvarivo samo u prijateljstvu s Bogom, no pitanje takvog odnosa nije moguće filozofski razraditi jer svako prijateljstvo uključuje zajednički život i konaturalnost u djelovanju. Zato je koncepcija prijateljstva s Bogom nastala tek unutar kršćanske teologije. Prema tom nauku, Bog privlači čovjeka kao njegovo krajnje dobro i djeluje u onom najintimnijem svakog ljudskog djelovanja na način da čovjek postaje dionikom božanske naravi i blaženstva, nakon svoje smrti.

Na taj način čovjek, koji se u svom traženju sreće usmjerio k izgradnji prijateljskih odnosa s drugom osobom i s Bogom, ostvaruje u svojoj osobi jedinstvo subjektivnosti i objektivnosti, imanencije i transcendencije, primanja i davanja. 


\section{Maja Herman Duvel* \\ Homo Amicus: The Being of Happiness, Well-being and Beatitude \\ Summary}

A man is a seeker of happiness because he is a person. That is why the question of human happiness includes moral life, but it also transcends it. The purpose of moral life is the good by which human action and man himself become good. Such good are virtues, but man, because of his fragility and helplessness, finds it difficult to acquire them. That is why true friendship is a privileged place and help for growth in virtue and joy of life. Friendship can also be a stimulating environment for a diligent search for truth and a contemplation of God, which is the source of human eudaimonia. But despite their value, human friendship and philosophical wisdom remain limited. Man cannot fulfil his desire for love, truth, and perfection by his own efforts. That is why Christian theology complements philosophy with the concept of friendship with God. This friendship leads to the perfect realization of the human person and to the unity of subjectivity and objectivity, immanence and transcendence, receiving and giving, which began with human friendship.

Key words: beatitude, friendship, God, happiness, person.

(na engl. prev. Maja Herman Duvel)

\footnotetext{
* Maja Herman Duvel, mag. phil., University of Zagreb, Faculty of Croatian Studies; Address: Borongajska 83d, HR-10000 Zagreb, Croatia; E-mail: maja.herman3@gmail.com.
} 